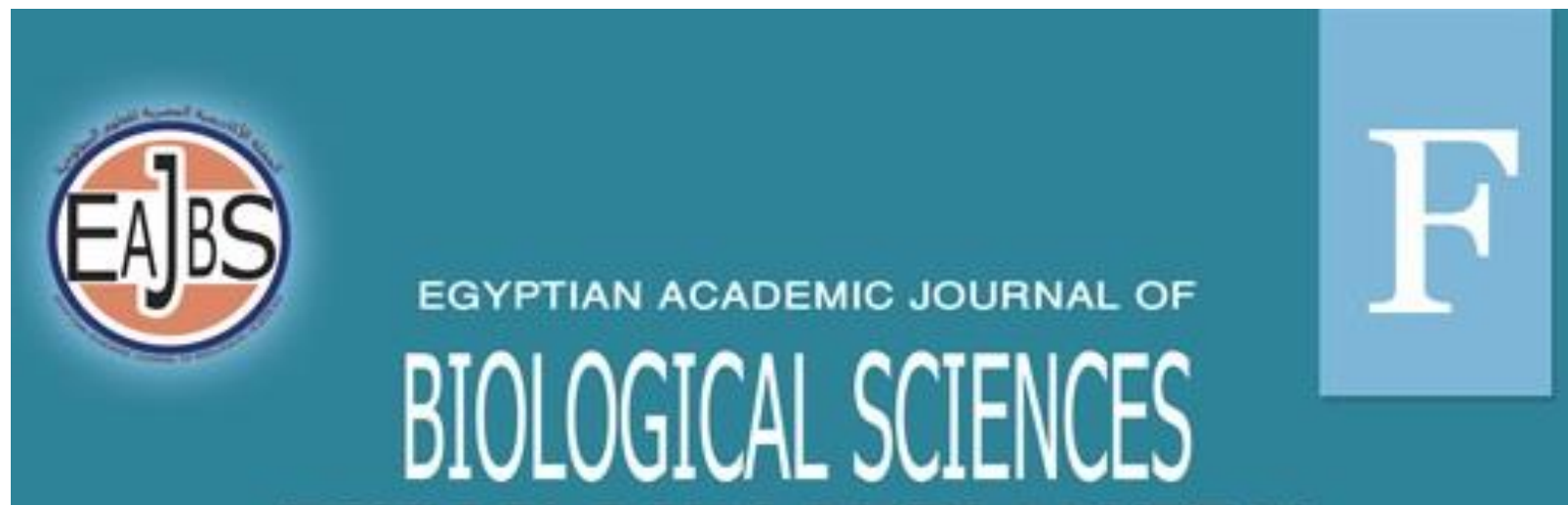

TOXICOLOGY \& PEST CONTROL

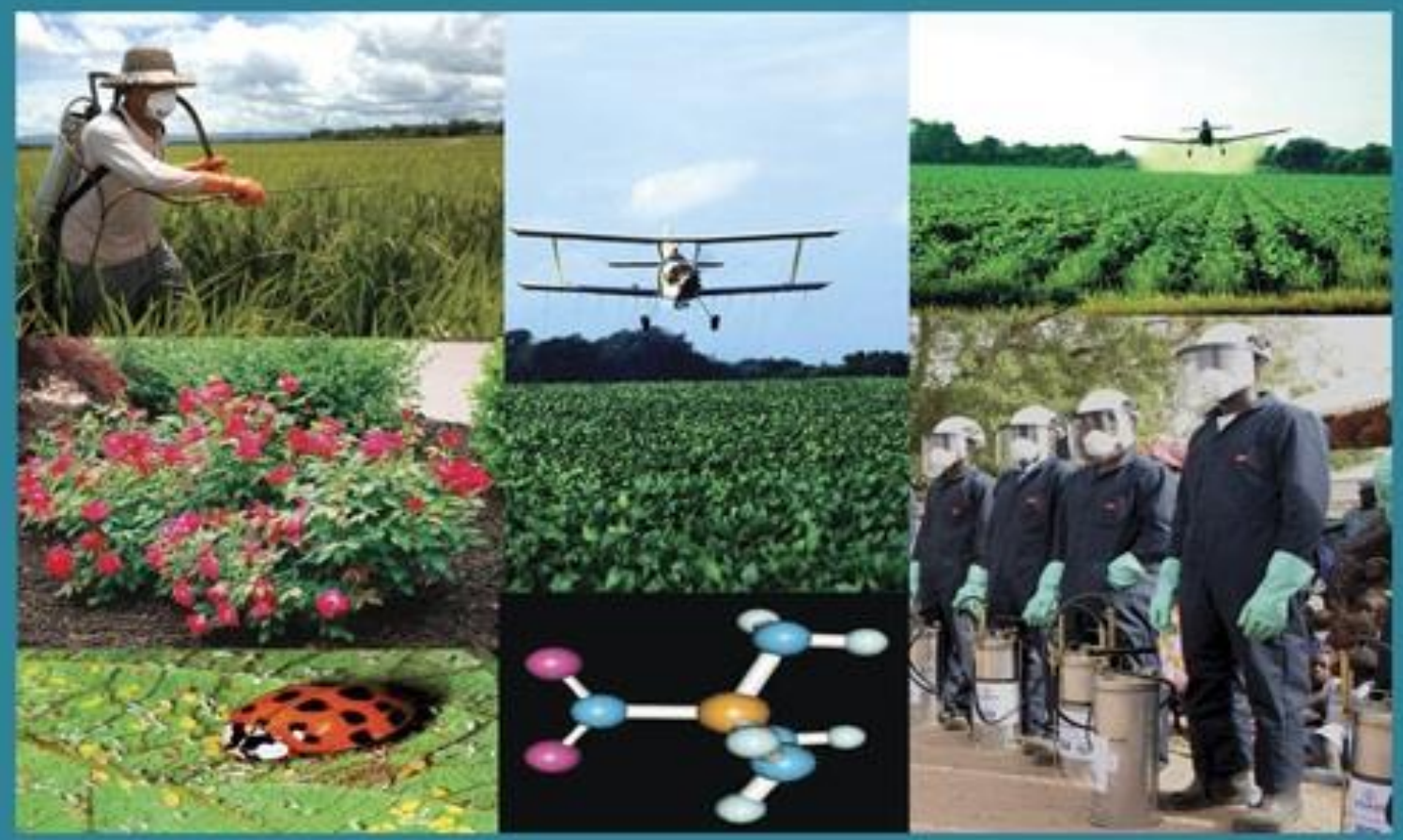

ISSN

2090-0791

WWW.EAJBS.EG.NET

Vol. 13 No. 1 (2021)

$\underline{\text { www.eajbs.eg.net }}$

Citation: Egypt. Acad. J. Biolog. Sci. (F.Toxicology \& Pest control) Vol.13(1)pp217-225(2021)

DOI: 10.21608/EAJBSF.2021.164317 
Egypt. Acad. J. Biolog. Sci., 13(1):227- 235 (2021)

Egyptian Academic Journal of Biological Sciences

F. Toxicology \& Pest Control

ISSN: 2090 - 0791

http://eajbsf.journals.ekb.eg/

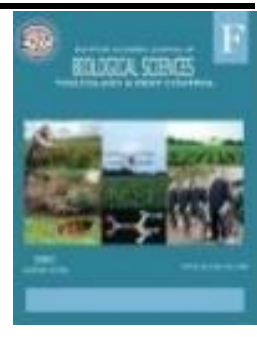

\section{Performance of Certain Insecticides against Pegomia mixta on Sugar Beet Crop in Egypt}

Massoud, M. A. ${ }^{1}$, A. Abdel-Megeed ${ }^{1}$., R. A. Shawer ${ }^{1}$, A.S.T. Barakat ${ }^{2}$, M. K. Abdelfatah $^{1}$ and A.M. Kordy ${ }^{1}$

1-Plant Protection Dept., Faculty of Agric. (Saba Basha) - Alex. Univ., Egypt. 2-Field Crop Pests Research Dep., Plant Protection Research Institute, Agricultural Research Center, Sabahia, Baccous, Alexandria, Egypt.

*E-Mail: aagric@yahoo.com

\section{ARTICLE INFO}

Article History

Received: $17 / 1 / 2021$

Accepted: 22/3/2021

\section{Keywords:}

Pegomia mixta,

SugarBeet,

Emamectin,

benzoate,

Azadirachtin,

Indoxacarb

Thiamethoxam,

spintoram,

profenofos

\section{ABSTRACT}

The present study was carried out throughout the two successive seasons of 2018/2019 and 2019/2020 at Nubaria region, Behaira Governorate, Egypt. Results revealed that during the first season (2018/2019), the general mean of reduction percentages throughout the whole inspection period showed that profenofos and spintoram were the most effective treatments against $P$. mixta which infest sugar beet where the highest general mean of reduction percentage were $92.43 \%$ and $83.22 \%$ reductions, followed by reductions of $66.76 \%, 62.10 \%$ and $58.57 \%$ for azadirachtin, Tuflobenzuron and Emamectin benzoate,, respectively, without significant variations. The least effective was diazinon 42.43, Indoxacarb 30.08, Lambda-Cyhalothrin $28.81 \%$, and thiamethoxam $12.43 \%$, subsequently, without significant differences. Moreover, in the second season (2019/2020), the highest general mean of reduction percentage showed profenofos and spintoram recorded the highest general means of $91.55 \%$, and $68.36 \%$ reductions, successively, followed by mean reductions of $65.08 \%, 64.44 \%$, and $52.2 \%$ for Emamectin benzoate, Diazinon, and tuflobenzuron, respectively, without significant variations. The least effective ones have corresponded to Azadirachtin 48.27\%, Indoxacarb $24.67 \%$, Lambda-Cyhalothrin $16.24 \%$, and thiamethoxam $(11.55 \%)$ subsequently, with significant differences.

The economics and profits were calculated for some insecticides singly to give comparatively high yields compared to the control. The insecticide of Spintoram, indoxacarb, and Azadirachtin gave high root yields of 40, ,39 and 39 ton/fed, in respect, on average, especially the insecticide of Spintoram represented the highest production of sugarbeet yield and the averages of top yields were 7,6 and $6 \mathrm{~kg} / \mathrm{fed}$ for the insecticide of spintoram, indoxacarb, and azadirachtin, respectively. Spintoram gave the highest (L.E. 25390) net returns/fed. and subsequently indicated the utmost profit of one Egyptian pound of L.E 9.26. Azadirachtin recorded L.E. 23902 and L.E. 7.39 for the net returns/fed. and the profits of one Egyptian pound investment, in sequence, compared to the untreated check. 


\section{INTRODUCTION}

Sugar beet (Beta vulgaris L.) is one of the main two sugar crops in Egypt. It is cultivated in 608.6 thousand feddans with an average production of about 18.5 tons per feddan in 2018/2019 (Annual report of sugar crops council, 2020). Indeed, the gap between consumption and sugar production was estimated at 5000 tons (Afifi, 2001). Thus, increasing the cultivated area and maximizing yield production of sugar beet have been considered as strategic goals of the ministry of agriculture in Egypt. The importance of this crop is not only to produce sugar but also to use its top in feeding animals due to the high nutritive value of the sugar beet canopy. Besides, sugar beet thrives well in poor, saline, alkaline, and calcareous soils; especially, in the newly reclaimed soils.

Sugar beet plants are attacked by numerous insect pests during their different growth stages (Mousa, 2005, El-khouly, 2006, Amin et al., 2008 and Fouad, 2011). Sugarbeet crop attracts considerable numbers of the sugar beet fly, Pegomia mixta Vill. (Diptera: Anthomyiidae) which negatively decreases the quantitative and qualitative sugar yield. This sugarbeet fly is a very serious insect pest that threatens sugarbeet plants (Zarif and Hegazi, 1990, Cooke and Scott, 1993 and Kandil, 2016). P. mixta is a key pest of sugar beet in Egypt since it causes great damage and crop loss (Al-Habshy et al., 2018). The insect has 3-4 peaks of eggs, while the larval population recorded 2-3 peaks of abundance. The highest average number of eggs and larvae observed in April. (Awadalla et al.,1991 and 1992; Youssef 1994; Abou-Attia 1999; Abou-ElKassem 2010 Bazazo 2010 and Bazazo et al. 2017) (Al-Habshy et al., 2018).

Therefore, the current study aimed to evaluate the efficacy of some novel insecticides that represent different chemical groups singly on the larvae of the sugarbeet fly, Pegomia mixta Vill. during the winter seasons of 2018/2019 and 2019/2020., and calculate the economics and profits of applying some insecticide mixtures against both the abovementioned insect pest infesting sugar beet plants in the two seasons of 2018/2019 and $2019 / 2020$.

\section{MATERIALS AND METHODS}

\section{Field Design:}

Field experiments were carried out on a private farm in Nubaria region, Egypt $\left(30.6667^{\circ} \mathrm{N} 30.0667^{\circ} \mathrm{E}\right)$. These field experiments were conducted during the two winter growing seasons of sugar beet in 2018/2019 and 2019/2020. The experimental plots were cultivated with sugar beet seed (Lodata cv.) as a polygerm type on $5^{\text {th }}$ October in both seasons. However, the harvesting date was on $25^{\text {th }}$ April in the $1^{\text {st }}$ and $2^{\text {nd }}$ seasons.

A complete block randomized design with three replications was used. The replicate area was $21 \mathrm{~m}^{2}(1 / 200 \mathrm{fed})$, with $6 \mathrm{~m}$ in length and $3.5 \mathrm{~m}$ width i.e. six ridges. Sugar beet balls were hand sown 1balls/hill using the dry sowing method on one side of the ridge in hills $15 \mathrm{~cm}$ apart and irrigated immediately after sowing directly. All other agricultural practices were applied at the recommendations of the Egyptian Ministry of Agriculture.

\section{Field Experiments:}

Nine insecticides were tested singly against the larvae of the sugarbeet fly, $P$. mixta during the winter seasons of 2018/2019 and 2019/2020. The insecticides were sprayed when the infestation reached the economic threshold level according to the recommended doses of the Egyptian Ministry of Agriculture. These insecticides were applied at the recommended doses of the Egyptian Ministry of Agriculture against the sugar beet fly, Pegomia mixta. 
Buffer areas of two ridges between every two adjacent plots were planted with sugar beet plants to avoid any contamination or interference of spray drift. The evaluated chemicals with their rates of applications were shown in Table (1).

Table 1: Rates of the used insecticides during the two sugarbeet winter seasons of 2018/2019 and 2019/2020.

\begin{tabular}{|c|c|c|c|}
\hline Chemical group & Active ingredient & Trade name & Application rate \\
\hline Spinosynes & Spinetoram & Radiant $12 \% \mathrm{SC}$ & $100 \mathrm{cc} /$ Feddan \\
\hline Organophosphates & Profenofos & Selecron $72 \%$ EC & $750 \mathrm{cc} /$ Feddan \\
\hline Oxadiazine & Indoxacarb & Avaunt $15 \% \mathrm{SC}$ & $105 \mathrm{cc} /$ Feddan \\
\hline Avermectines & Emamectin benzoate & New claim ${ }^{\circledR} 5 \%$ WG & $100 \mathrm{~g} /$ Feddan \\
\hline Pyrethroids & Lambda-Cyhalothrin & Axon $(5 \%$ EC & $200 \mathrm{cc} /$ Feddan \\
\hline Organophosphates & Diazinon & Diazinon $60 \%$ EC & $750 \mathrm{cc} /$ Feddan \\
\hline Diacylhydrazines & Tuflobenzuron & Nomolt $24 \%$ SC & $1 / 2 \mathrm{cc} /$ Feddan \\
\hline Limonoids (Triterpenoides) & Azadirachtin & Achock $\circledR^{\circledR} 5 \% \mathrm{EC}$ & $5 \mathrm{cc} / 1$ liter water \\
\hline Nicotinoid & Thiamethoxam & Actara ${ }^{\circledR 2} 25 \% \mathrm{WG}$ & $20 \mathrm{~g} / 100$ liter water \\
\hline
\end{tabular}

$\mathbf{E C}=$ Emulsifiable Concentration, $\mathbf{S C}=$ Suspension Concentration and $\mathbf{W G}=$ Granules or Tablets Water Dispersible.

\section{Sampling Technique:}

For counting the occurrence of $P$. mixta (larvae)/ 15 plants were collected at random from each plot before treatments and at 1, 3, 5, 7 and 10 days after initiating the insecticidal spray.

\section{Infestation Reduction:}

The infestation of both insects has investigated pre-treatment and after 1, 3-, 5-, 7-, and 10-days post-treatment, the mean reduction percentages were calculated according to Henderson and Tilton (1955).

the equation as follows:

$$
\text { Reduction \% }=1-\left[\frac{\mathrm{A}}{\mathrm{B}} \times \frac{\mathrm{C}}{\mathrm{D}}\right] \times 100 \text {, where }
$$

R: \% Mean reduction of the insect population.

A: \% Mean no. of larvae in treatment after spraying.

B: \% Mean no. of larvae in treatment before spraying.

C: \% Mean no. of larvae in untreated check (control) before spraying.

D: \% Mean no. of larvae in check after spraying.

Economics and Profits of Certain Singly Insecticides as Compared with Control against $P$. mixta Infesting Sugarbeet Plants During the Second Sugarbeet Winter Season of 2019/2020:

In this regard, the experiment was carried out in the same private field, for computing the economics and profits for $P$. mixta by applying some singly insecticides. The experimental area was divided longlidunally into 3 blocks; in turn, each block was subdivided into 10 plots of $21 \mathrm{~m}^{2}$, each. Buffer areas of two ridges between every two adjacent plots were planted with sugar beet plants to avoid any contamination or interference of spray drift. Each insecticide was applied once coinciding with the economic thresholds (ETs) for P. mixta. Sugarbeet plants were sprayed with some insecticides singly by using a Knapsack sprayer (20 1), at the rate of 400 liters / feddan.

Singly insecticides, root yields (Ton/fed.), top yields (Kg/fed.), \% sucrose, roots income (L.E / Fed.), top yield income (L.E / Fed.), gross income (L.E / Fed.), input costs 
(total costs) included both insecticide costs (L.E / Fed.) and labour costs (L.E / Fed.), net returns (L.E / Fed.), additional returns over the untreated control, and profit for one Egyptian pound investment (L.E / Fed.). These consequent calculations were done, in order, to determine the most profitable singly insecticides to be followed by the growers according to the procedure of Le-Docte (1927) and Kandil (2016).

Statistical Analysis:

Data of this study were subjected to the regression line analysis for the determination of the analysis of variance ANOVA using " $F$ " Test following the Randomized Complete Block Design (RCBD), with three replications for each treatment for the remaining experiments. The least significant differences (L.S.D) at the $0.05 \leq$ level were determined according to a computer program (Costat software, 1988) and Duncan's Multiple Range Testes modified by Steel and Torrie (1981) to compare the mean numbers of the different treatments of the inspected insects.

\section{RESULTS AND DISCUSSION}

Effect of some insecticides against the sugarbeet fly, $P$. mixta infesting (Lodata) cv. sugarbeet plants during both seasons of 2018/2019 and 2019/2020.

The included results in Tables ( 2 and 3 ) pointed to the reduction percentages of the sugarbeet fly, larvae of $P$. mixta after 1, 3, 5, 7, and 10 days from initiating the spray of the assigned chemicals on sugarbeet plants during the two successive winter seasons of 2018/2019 and 2019/2020.

Results of the first season of 2018/2019 were listed in Table (2) and shown in Fig. (1). Data referred to the tested compounds, efficacy on the key insect pest, as they have been varied according to their mode of action, for example, as a general mean, profenofos and spintoram came on the top of all the treatments, in recording the highest general means $92.43 \%$ and $83.22 \%$ reductions, followed by reductions of $66.76 \%, 62.10 \%$ and $58.57 \%$ for azadirachtin, Diazinon and Emamectin benzoate, respectively, without significant variations. The least effective was Tuflobenzuron $42.43 \%$, Indoxacarb $30.08 \%$, lambdacyhalothrin $28.81 \%$, and thiamethoxam $12.43 \%$, subsequently, without significant differences also as shown in (Table, 2 and Fig. 1).

In the second season of 2019/2020, the statistical analysis showed that profenofos and spintoram topped all the tested treatments, as they recorded the highest general means of $91.55 \%$, and $68.36 \%$ reductions, successively, followed by mean reductions of $65.08 \%$, $64.44 \%, 52.20 \%$ and $28.27 \%$ for emamectin benzoate, diazinon, tuflobenzuron, and azadirachtin, respectively, without significant variations. The least effective ones were corresponded to indoxacarb $24.67 \%$, Lambda-Cyhalothrin $16.24 \%$, and thiamethoxam (11.55\%) subsequently, with significant differences, as concluded in (Table, 3 and Fig. 2).

Results of this study, to some extent, were in agreement with those of other researchers. For example, in Egypt, Bassyouny and Khalafalla (1996) reported that carbosulfan was significantly effective than profenofos against the sugarbeet fly, $P$. mixta in both irrigated and non-irrigated sugarbeet fields. It appeared also that irrigation did not significantly affect the toxicity of carbosulfan to the considered insect pest. Abo El-Ftooh et al. (2012) observed that all the tested insecticides in two locations significantly reduced the population density of $P$. mixta on sugar beet plants compared to the check treatment. The population has been increased as the elapsed time increased in the treatment of Selecron $72 \%{ }^{\circledR}$ and was the most effective chemical against $P$. mixta followed by Tracer $24 \%{ }^{\circledR}$, Vertimec $1.8 \%{ }^{\circledR}$, and Nudrin $90 \%{ }^{\circledR}$. Kandil (2016) found that profenofos, chlorantraniliprole, azadirachtin, and imidacloprid were the most potent chemicals among all treatments against P. mixta during 2014/2015 and 2015/2016 winter seasons. 
Table 2: Efficacy of some insecticides sprayed singly beside the larvae of $P$. mixta infesting (Lodata) cv. sugarbeet plants during the first season of 2018/2019.

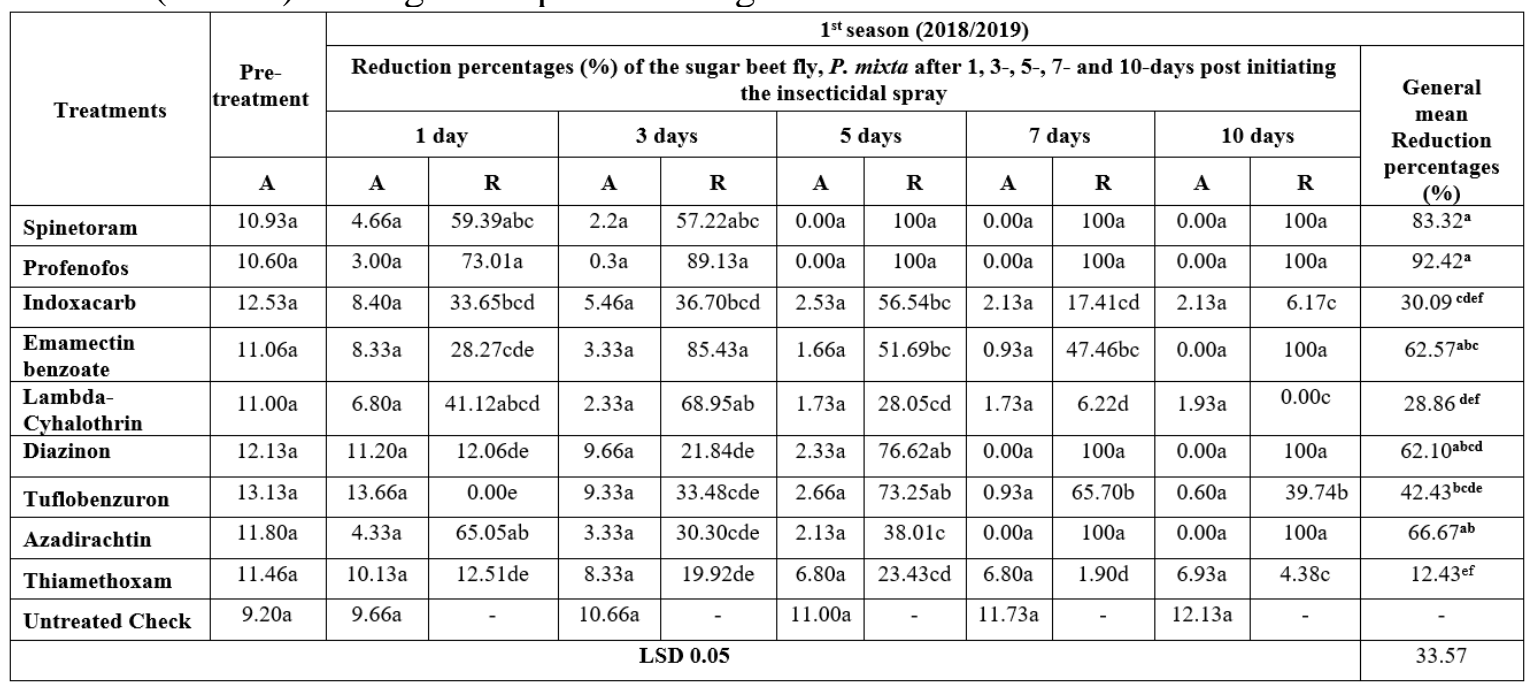

A: mean number of larvae / plants.

$\mathbf{R}$ : reduction percentage of infestation after insecticide application.

* Means followed by the same letter(s) in each column are not significantly different at $\mathrm{P} \leq 0.05$ level.

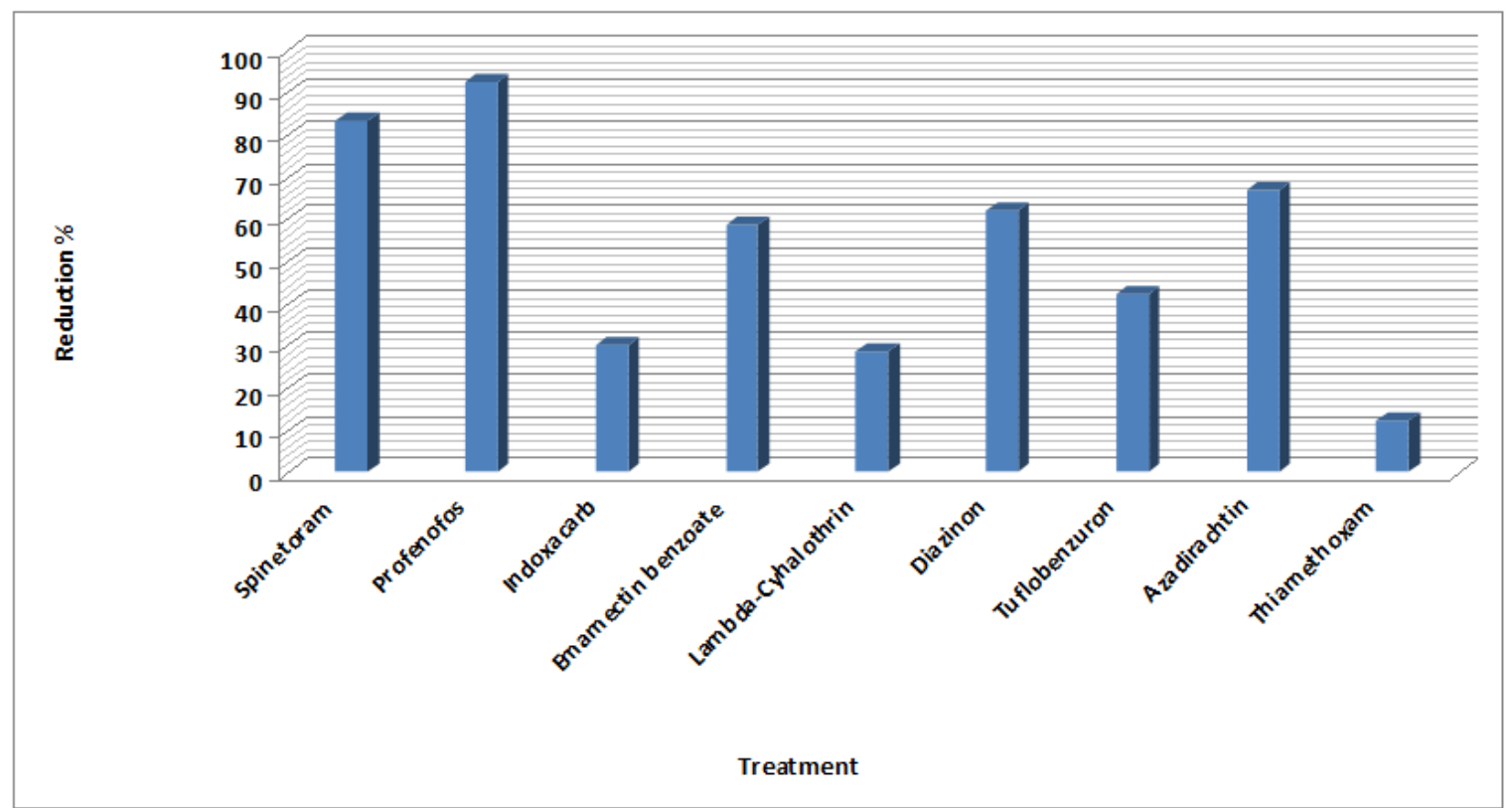

Fig. 1. General mean reduction percentages against the larvae of $P$. mixta infesting (Lodata) cv. sugarbeet plants during the first season of 2018/2019. 
Table 3:Efficacy of some novel insecticides sprayed singly against the larvae of $P$. mixta infesting (Lodata) cv. sugarbeet plants during the second season of 2019/2020.

\begin{tabular}{|c|c|c|c|c|c|c|c|c|c|c|c|c|}
\hline \multirow{4}{*}{ Treatments } & \multirow{4}{*}{$\begin{array}{c}\begin{array}{c}\text { Pre- } \\
\text { treatment }\end{array} \\
\text { A }\end{array}$} & \multicolumn{11}{|c|}{$2^{\text {nd }}$ season $(2019 / 2020)$} \\
\hline & & \multicolumn{10}{|c|}{$\begin{array}{c}\text { Reduction percentages (\%) of the sugar beet fly, } P \text {. mixta after 1, 3-, 5-, 7-, and 10-days post } \\
\text { initiating the insecticidal spray }\end{array}$} & \multirow{3}{*}{$\begin{array}{c}\text { General mean } \\
\text { Reduction } \\
\text { percentages } \\
(\%)\end{array}$} \\
\hline & & \multicolumn{2}{|c|}{1 day } & \multicolumn{2}{|c|}{3 days } & \multicolumn{2}{|c|}{5 days } & \multicolumn{2}{|c|}{7 days } & \multicolumn{2}{|c|}{10 days } & \\
\hline & & $\mathbf{A}$ & $\mathbf{R}$ & $\mathbf{A}$ & $\mathbf{R}$ & $\mathbf{A}$ & $\mathbf{R}$ & $\mathbf{A}$ & $\mathbf{R}$ & $\mathbf{A}$ & $\mathbf{R}$ & \\
\hline Spinetoram & $11.33 \mathrm{a}$ & $8.00 \mathrm{a}$ & $30.33 \mathrm{ab}$ & $5.33 \mathrm{a}$ & $35.11 \mathrm{bc}$ & $1.33 \mathrm{a}$ & 76.59ab & $0.00 \mathrm{a}$ & $100 \mathrm{a}$ & $0.00 \mathrm{a}$ & $100 \mathrm{a}$ & $68.36^{\mathrm{ab}}$ \\
\hline Profenofos & $12.80 \mathrm{a}$ & $5.46 \mathrm{a}$ & $57.78 \mathrm{a}$ & $0.00 \mathrm{a}$ & $100 \mathrm{a}$ & $0.00 \mathrm{a}$ & $100 \mathrm{a}$ & $0.00 \mathrm{a}$ & $100 \mathrm{a}$ & $0.00 \mathrm{a}$ & $100 \mathrm{a}$ & $91.55^{\mathrm{a}}$ \\
\hline Emamectin benzoate & $10.66 \mathrm{a}$ & $8.00 \mathrm{a}$ & $25.72 \mathrm{ab}$ & $5.66 \mathrm{a}$ & $25.35 \mathrm{~cd}$ & $1.55 \mathrm{a}$ & 74.31ab & $0.00 \mathrm{a}$ & $100 \mathrm{a}$ & $0.00 \mathrm{a}$ & $100 \mathrm{a}$ & $65.08^{\mathrm{ab}^{*}}$ \\
\hline Lambda-Cyhalothrin & $10.00 \mathrm{a}$ & $8.80 \mathrm{a}$ & $12.90 \mathrm{~b}$ & $5.33 \mathrm{a}$ & $41.01 \mathrm{bc}$ & $4.13 a$ & $27.32 \mathrm{~cd}$ & $4.80 \mathrm{a}$ & $0.00 \mathrm{~b}$ & $5.13 a$ & $0.00 \mathrm{~b}$ & $16.24^{\mathrm{cd}}$ \\
\hline Diazinon & $11.66 \mathrm{a}$ & $9.00 \mathrm{a}$ & $23.60 \mathrm{ab}$ & $6.00 \mathrm{a}$ & $35.07 \mathrm{bc}$ & $2.33 \mathrm{a}$ & $63.57 \mathrm{~b}$ & $0.00 \mathrm{a}$ & $100 \mathrm{a}$ & $0.00 \mathrm{a}$ & $100 \mathrm{a}$ & $64.44^{\mathrm{ab}}$ \\
\hline Tuflobenzuron & $12.66 \mathrm{a}$ & $13.13 \mathrm{a}$ & $0.00 \mathrm{~b}$ & $10.33 \mathrm{a}$ & $23.38 \mathrm{~cd}$ & $2.66 \mathrm{a}$ & 75.84ab & $0.00 \mathrm{a}$ & $100 \mathrm{a}$ & $0.00 \mathrm{a}$ & $100 \mathrm{a}$ & $59.84^{\mathrm{ab}}$ \\
\hline Azadirachtin & $12.00 \mathrm{a}$ & $8.40 \mathrm{a}$ & $30.71 \mathrm{ab}$ & $5.46 \mathrm{a}$ & $36.70 \mathrm{bc}$ & $2.53 \mathrm{a}$ & $56.54 \mathrm{bc}$ & $2.13 \mathrm{a}$ & $17.41 \mathrm{~b}$ & $0.00 \mathrm{a}$ & $100 \mathrm{a}$ & $48.27^{\mathrm{bc}}$ \\
\hline \multicolumn{12}{|c|}{ LSD 0.05} & 34.41 \\
\hline
\end{tabular}

A: mean number of larvae and adults / plant.

R: reduction percentage of infestation after insecticide application.

* Means followed by the same letter(s) in each column are not significantly different at $\mathrm{P} \leq 0.05$ level.

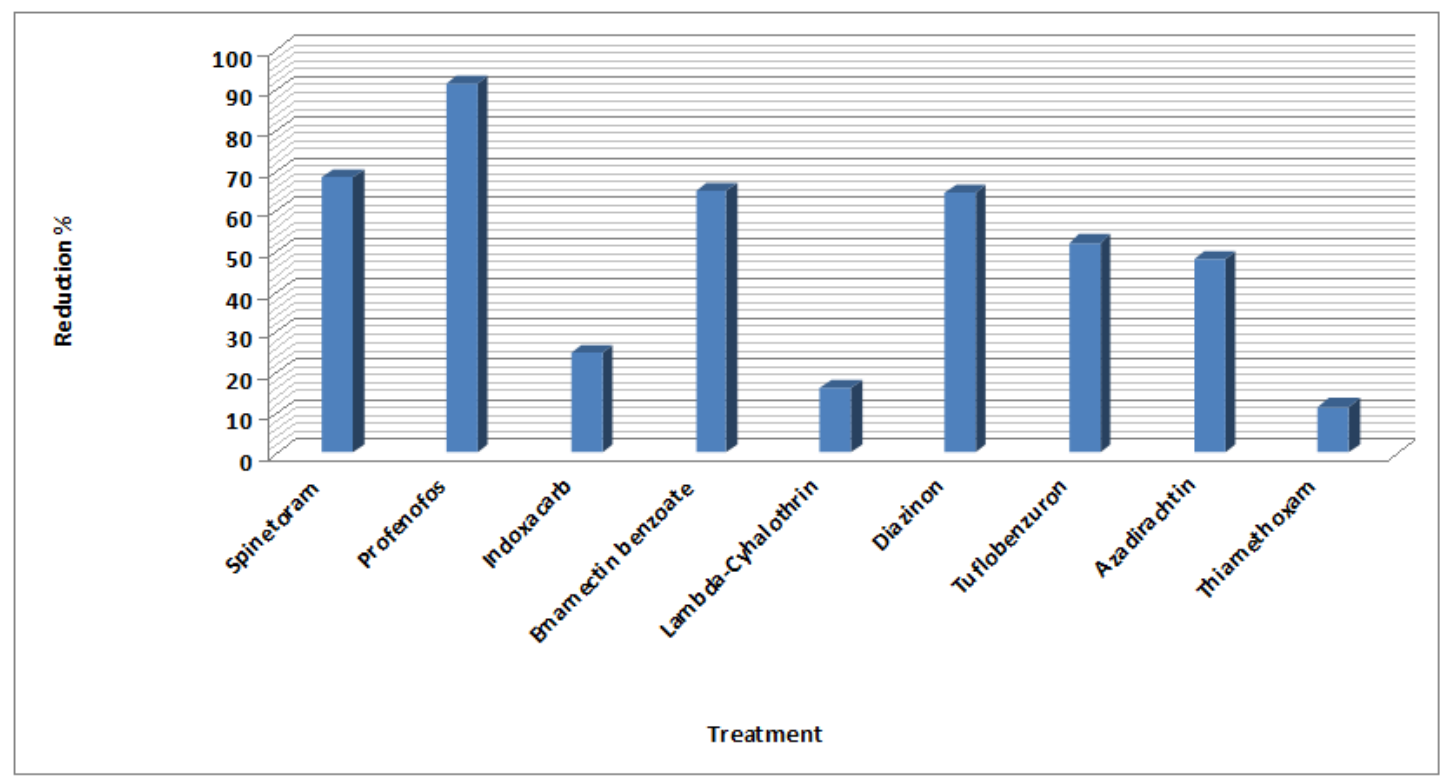

Fig. 2. General mean reduction percentages against the larvae of $P$. mixta infesting (Lodata) cv. sugarbeet plants during the second season of 2019/2020.

Economics and Profits of Insecticide as Compared with Control against $P$. mixta Infesting (Lodata) cv. Sugarbeet Plants During the Second Season of 2019/2020:

The control costs and benefits were determined for $P$. mixta in the sugarbeet plants (Lodata cultivar) during the second season of 2019/2020.

The economics and profits were calculated for some insecticides singly to give comparatively high yields compared to the control.

Assuming that all the plots that were sprayed with the insecticides singly from Spintoram to Thiamethoxam and controls were similar in their production inputs (constant service costs) and differ only in the control costs. Therefore, the accountant particulars concerning their values were explained clearly as follows: 
The insecticide of Spintoram, indoxacarb, Lambda-Cyhalothrin, and Azadirachtin gave high root yields of 40.00, 39, 39, and 38ton/fed, in respect, on average, especially the insecticide of Spintoram represented the highest production of sugarbeet yield.

Likewise, the averages of top yields were 7, 6, 5, and $6 \mathrm{~kg} / \mathrm{fed}$ for the insecticide of Spintoram, indoxacarb, Lambda-Cyhalothrin, and Azadirachtin, respectively. It is worth mentioning that sugarbeet roots increased parallel to the increase in top yields.The insecticide spray increased the sugarbeet production (roots and tops) at varying levels rather than the controls. Spintoram gave the highest (L.E. 25390) net returns/fed. and subsequently indicated the utmost profit of one Egyptian pound of L.E 9.26. Azadirachtin recorded L.E. 23902 and L.E. 7.39 for the net returns/fed. and the profits of one Egyptian pound investment, in sequence, compared to the untreated check. On the other hand, Indoxacarb recorded L.E. 24136 and L.E. 6.42, followed by Lambda-Cyhalothrin L.E. 23515 and L.E. 6 , for the same net returns and profits, successively. Emamectin benzoate recorded also L.E. 22350 and L.E. 2, for the same net returns and profits, consequently for each. Thiamethoxam, Profenofos and Diazinon showed the least net returns of 22220, 21910 , and 21660 for net returns and 1.21, 0.56, and 0.30 for-profits, in respect, compared to the check.

Therefore, the applied singly insecticides could be arranged in descending order as follows: Spintoram > Azadirachtin > indoxacarb > Lambda-Cyhalothrin > Tuflobenzuron > Emamectin benzoate > Thiamethoxam > Profenofos > Diazinon that means Spintoram, Azadirachtin and indoxacarb gave the highest profits to the grower but Tuflobenzuron $>$ Emamectin benzoate $>$ Thiamethoxam $>$ Profenofos $>$ Diazinon gave the least profits for the producer.

It is of great importance to conclude that the check (treated with no chemicals) gave L.E 21757.5 as net returns/fed. and that was higher than that of Spintoram; this phenomenon was due to the least total costs/fed. as compared to the higher costs in the applied insecticide of Azadirachtin, indoxacarb, Lambda-Cyhalothrin, Tuflobenzuron, Emamectin benzoate, Thiamethoxam, Profenofos, and Diazinon (Table, 4).

Table 4: Economics and profits of certain singly insecticide as compared with control against $P$. maxi infesting (Blackman and Eastop) cv. sugarbeet plants during the second winter season of 2019/2020.

\begin{tabular}{|c|c|c|c|c|c|c|c|c|c|c|c|c|c|}
\hline \multirow{2}{*}{$\begin{array}{l}\text { Insecticides } \\
\text { Mixtures } \\
\text { (Treatments) }\end{array}$} & \multirow{2}{*}{$\begin{array}{c}\text { No. of } \\
\text { insecticide } \\
\text { applications }\end{array}$} & \multirow[b]{2}{*}{$\begin{array}{c}\text { Root } \\
\text { yields } \\
\text { (ton / } \\
\text { feddan) }\end{array}$} & \multirow{2}{*}{$\begin{array}{c}\text { Top } \\
\text { yields } \\
\text { (ton / } \\
\text { feddan) }\end{array}$} & \multirow{2}{*}{$\begin{array}{c}\% \\
\text { sucrose }\end{array}$} & \multirow{2}{*}{$\begin{array}{c}\text { Roots } \\
\text { income }\end{array}$} & \multirow{2}{*}{$\begin{array}{c}\text { Top } \\
\text { yields } \\
\text { income }\end{array}$} & \multirow[b]{2}{*}{$\begin{array}{c}\text { Biological } \\
\text { returns } \\
\text { (Gross } \\
\text { income / } \\
\text { feddan) } \\
\text { (L.E) (c) }\end{array}$} & \multicolumn{3}{|c|}{ Input costs / feddan (L.E) } & \multirow{2}{*}{$\begin{array}{c}\text { Net } \\
\text { returns / } \\
\text { feddan }\end{array}$} & \multirow[b]{2}{*}{$\begin{array}{c}\text { Additional } \\
\text { returns } \\
\text { over } \\
\text { untreated } \\
\text { control } \\
\text { (L.E) (g) }\end{array}$} & \multirow[b]{2}{*}{$\begin{array}{c}\text { Profit of } \\
\text { one } \\
\text { Egyptian } \\
\text { pound } \\
\text { investment } \\
\text { (L.E) (h) }\end{array}$} \\
\hline & & & & & & & & $\begin{array}{l}\text { Treatments } \\
\begin{array}{c}\text { costs / } \\
\text { feddan }\end{array} \\
\text { (L.E) }\end{array}$ & $\begin{array}{c}\begin{array}{c}\text { Labour } \\
\text { wages / } \\
\text { feddan }\end{array} \\
\text { (L.E) (d) }\end{array}$ & $\begin{array}{c}\begin{array}{c}\text { Total } \\
\text { costs / } \\
\text { feddan }\end{array} \\
\text { (L.E)(e) }\end{array}$ & & & \\
\hline Spinetoram & 1.00 & 40.00 & 7.000 & 15.5 & 25200 & 560 & 25760 & 190 & 200 & 390 & 25370 & 3612.5 & 9.26 \\
\hline Profenofos & 1.00 & 35.00 & 6.000 & 15 & 21700 & 480 & 22180 & 70 & 200 & 270 & 21910 & 152.5 & 0.56 \\
\hline Indoxacarb & 1.00 & 39.00 & 6.000 & 14.7 & 23946 & 560 & 24506 & 170 & 200 & 370 & 24136 & 2378.5 & 6.42 \\
\hline Diazinon & 1.00 & 36.00 & 5.000 & 14 & 21600 & 400 & 22000 & 140 & 200 & 340 & 21660 & 97.5 & 0.30 \\
\hline Tuflobenzuron & 1.00 & 37.00 & 5.000 & 14.4 & 22496 & 400 & 22896 & 140 & 200 & 370 & 22526 & 768.5 & 2.00 \\
\hline Azadirachtin & 1.00 & 38 & 6.000 & 15.2 & 23712 & 480 & 24192 & 90 & 200 & 290 & 23902 & 2144.5 & 7.39 \\
\hline Thiamethoxam & 1.00 & 37.00 & 5.000 & 14 & 22200 & 400 & 22600 & 180 & 200 & 380 & 22220 & 462.5 & 1.21 \\
\hline Untreated Check & 0.00 & 35.00 & 4.000 & 14.62 & 21437.5 & 320 & 21757.5 & 0 & 0 & 0 & 21757.5 & 0 & 0 \\
\hline
\end{tabular}

(a) Worked out at L.E 600 / ton including an increase of L.E 100 for the early roots delivery to the factory and L.E. 20 for every increase over $14 \%$ sucrose.

(b) Worked out at L.E 80 / ton.

(c) Worked out as summation $(\Sigma)$ of roots income + top yields income.

(d) Worked out at L.E $200 /$ feddan $\times$ No. of sprays.

(e) Total costs of control $/$ feddan $=$ treatments costs + labour wages .

(f) Net returns $/$ feddan $=($ Gross income $/$ feddan $)-($ Total costs $/$ feddan $)$

(g) Additional returns $=$ Net returns of any mixture - control returns.

(h) Profit for one Egyptian pound $=$ Additional returns $\div$ Total costs. 


\section{REFERENCES}

Abo El-Ftooh A. A.; K. M. Agami and M. M. Abd-El-Rahman (2012). The effect of some organic manures and insecticides on sugarbeet productivity and population dynamic of beet fly, Pegomyia mixtavill. Journal of Plant Production Mansoura University, 3(3): 557-569.

Afifi, F. (2001). Developing of cultivation and production of sugar corps in Egypt (19812000) present and future vision of sugar industry. Egyptian Society of Sugar Technologists, the $31^{\text {st }}$ Annual Conference, Luxor, Egypt, 27-29 January, pp 7-19.

Bassyouny, A. M. and E. M. E. Khalafalla (1996). Fluctuations of certain insect pests on three sugarbeet varieties and their control. Alexandria Science Exchange Journal , Egypt,17(4): 381-393.

Cooke, D. A. and R. K. Scott (1993). The sugarbeet crop. 11-Pests. Published by Shapman and Hall. ISBN 0412251302 p. 429-83.

Costat software (1988). Microcomputer Program Analysis. Co-Hort Software, Berkely, CA, USA.

El-Khouly, M. I. (2006). Population fluctuations of the beet fly, Pegomyia mixtaVill. and the tortoise beetle, CassidavittataVill. in relation to certain associated natural enemies in sugarbeet fields at Kafr El-Sheikh Governorate, Egypt. Egyptian Journal of Biological Pest Control, 16(1): 25-28.

Fouad, H. A. M. (2011). Control some pests infesting sugarbeet in Sharkia Governorate. M. Sc. Thesis, Faculty of Agriculture, Mansoura University,pp. 172.

Henderson, C. F. and E. W. Tilton (1955). Tests with acaricides against the brown wheat mite. Journal of Economic Entomology, 48: 157-161.

Kandil, R. S. (2016). New trends for the control of Cassida vittataVill. and Pegomya hyoscyami Crutis infesting sugarbeet crop and assessment of yield losses in Nobaria region. Ph. D. Thesis, Faculty of Agriculture. (Saba Basha), Alexandria University. Egypt, pp. 84.

Le-Docte, A. (1927). Commerical determination of sugar in the beet root using the sacs Le-Decte Process. International Sugar Journal, 29:488-492.

Steel, R. G. D. and J. H. Torrie (1981). Principles and procedures of statistic. A biometrical approach. 2nd Ed. McGraw. Hill Kogahusha Ltd. PP. 633.

Zarif, G. and E. M. Hegazi (1990) Effect of nitrogen fertilization and sugarbeet cultivars on population of Pegomia mixtaVill. (Diptera, Anthomyidae) Com. Science and Development Research,29: 1-10. 


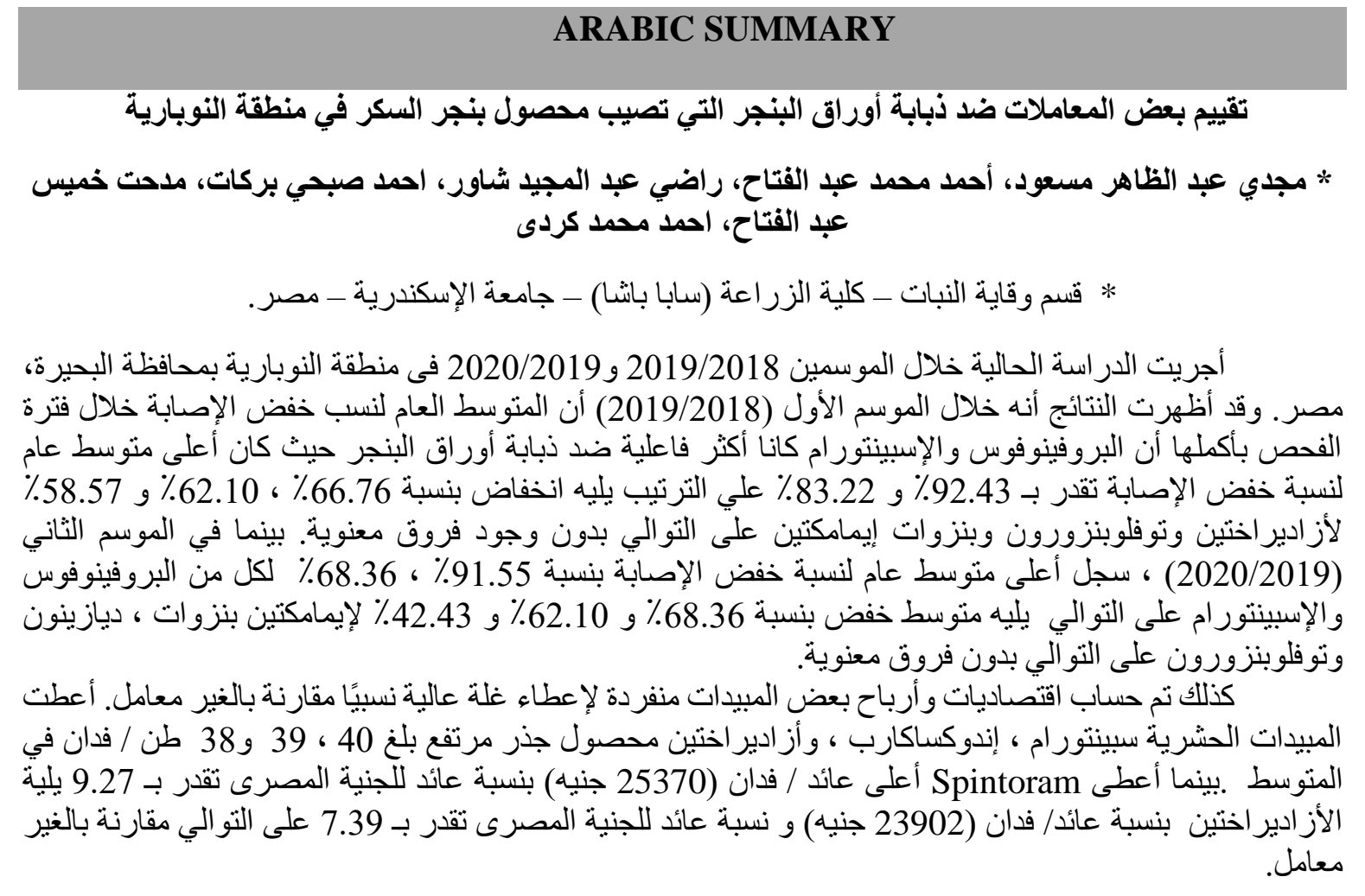

